\title{
The Dialogues project: Students as partners in developing research-engaged learning
}

\section{ABSTRACT}

This article explores the notion of students as partners in the development of a research-engaged teaching and learning project. Based on the premise that dialogue could form a bridge between students, artists and academics, the Dialogues project was first established in 2010 and has subsequently enabled a meaningful and sustainable partnership between staff and students to develop. Dialogues 2014: Place, Space and Negotiated Territories was the fifth iteration in a series of annual interdisciplinary Fine Art symposia, developed through an innovative partnership between undergraduate and postgraduate Fine Art students and staff at the Norwich University of the Arts (United Kingdom). Since its inception, Dialogues projects have engaged over 900 Fine Art students across all levels of study, through annual symposia and related events.

\section{INTRODUCTION}

In the forward to Engagement through Partnerships: Students as Partners in Learning and Teaching in Higher Education, published by the Higher Education Academy (HEA) in 2014, Professor Phillipa Levy states,

\section{KEYWORDS}

dialogue

integration participation partnership research-engaged team building 
Over recent years, higher education policy initiatives across the UK have emphasized the importance of students' active engagement in their learning, and the benefits to be gained when students play an active role in shaping and enhancing their learning experiences. 'Student engagement' has become a core aim for the sector and, increasingly, is being linked to ideas about students' roles as partners in their higher education communities.

(Healey et al. 2014: 4)

This project was conceived in the autumn of 2009, and the name 'Dialogues' was originally chosen as it best represented our aims: to provide students proximity to, and dialogue with, a range of artists, curators and academics whose practice and research is currently shaping and/or questioning the nature of a discipline. At this initial stage we primarily wanted to provide a trigger point within the academic year, and an event-based scenario was the most appropriate method to reach a wide audience. From the outset, we were keen to focus this project on the student experience, with opportunities for dialogue at a local level. We wanted to encourage a space for formality and informality to interchange, and to provide an arena for students to take ownership and responsibility for their own learning. As a student-centred professional activity, it was decided that the format for the Dialogues series should be based loosely on the conference model, with the student body as the delegates.

This article considers the development of the project over a five-year period, and is framed for the most part by the literature and theory associated with teaching and learning in higher education. While the content of each individual project was based on discipline-specific thematic enquiry, understanding the projects as a whole through wider generic teaching and learning models has increased our understanding of core values such as engagement, participation and student experience. From the outset in 2010, we were keen to define what a partnership should be in terms of the project objectives, and we agreed that the process of partnership was as critical as the outcome of the symposium itself. The unique environment of a small specialist university with its strong sense of community, and emphasis on practice-led research, helped to provide the conditions in which a meaningful partnership could develop and thrive. As a form of action research, we recognized the potential for this project to have a significant impact on student learning, and to open possibilities for greater integration between discrete student groups operating within the university. As a result, the project set out to increase the opportunity for student dialogue across postgraduate and undergraduate levels through an open platform for critical debate and knowledge exchange. Dialogues 2014: Place, Space and Negotiated Territories was the fifth iteration of the project, and had by this time firmly established itself as an annual feature of the academic calendar for undergraduate and postgraduate Fine Art students at Norwich University of the Arts. Each iteration has taken a new perspective or subject focus, although the primary objective to create a platform for dialogue with practitioners of national and international repute in the field has remained consistent.

\section{STUDENTS AS PARTNERS: DEVELOPING AN APPROACH}

In 2011, the Department for Business Innovation and Skills (BIS) published a White Paper that indicated that students should be more centrally engaged in the development of learning, including many areas of student engagement and 
curriculum design (2011). A number of funded projects in the United Kingdom followed, including the 'Student as producer', at the University of Lincoln, which according to their website aimed to 'make research - engaged teaching an institutional priority, across all faculties and subject areas. In this way students become part of the academic project of the University and collaborators with academics in the production of knowledge and meaning' (2013). In July 2014, the HEA published a Framework for Partnership in Learning and Teaching in Higher Education. The framework was a response to the increased awareness within the Higher Education sector on issues such as student engagement and the influence of partnership within teaching and learning. According to the framework,

Partnership is understood as a relationship in which all involved are actively engaged in and stand to gain from the process of learning and working together to foster engaged student learning and engaging learning and teaching enhancement. Partnership is essentially a way of doing things, rather than an outcome in itself.

(HEA 2014: 2)

The Framework developed by the HEA includes a conceptual model (see Figure 1), developed by Healey, Flint and Harrington in 2014 for students as

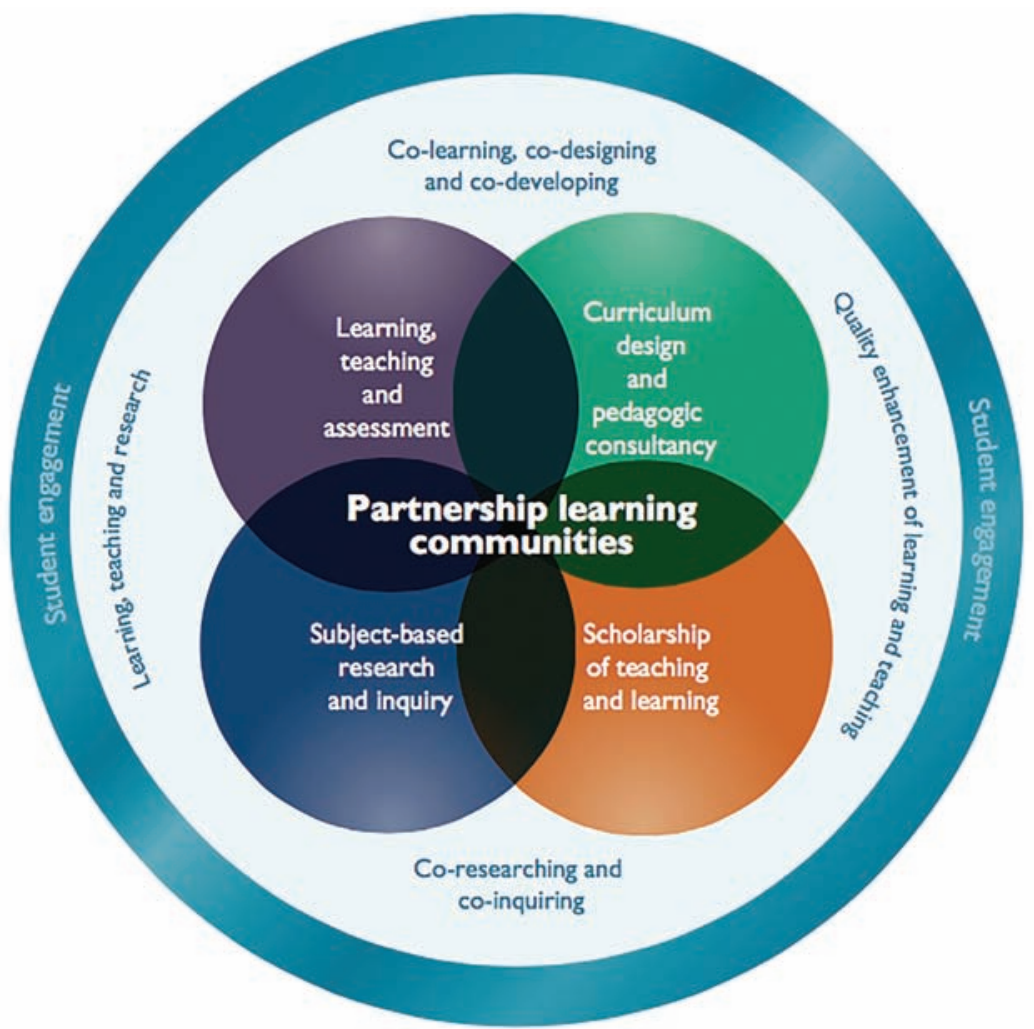

Figure 1: A conceptual model for students as partners in learning and teaching in higher education (Source: HEA 2014). 
partners in learning and teaching in higher education. It considers the case for partnership, and the principles and values associated with this kind of activity. The model situates four key areas where interrelationships are formed: learning, teaching and assessment; subject-based research and enquiry; scholarship of teaching and learning; and curriculum design and pedagogic consultancy. We recognized that areas such as inclusivity and community were of particular value to us in the development of student engagement and ownership over their own learning. In particular, we wanted to provide the conditions in which inspirational teaching could be transformative, an approach described by Paul Ramsden in Learning to Teach in Higher Education as 'making learning possible' (2006: 110).

The companion publication Engagement through Partnerships: Students as Partners in Learning and Teaching in Higher Education (2014) sets out a contextualized case for partnership. The notion that partnership, as suggested by Flint, should engender a method or approach to partnership rather than a focus purely on outcome, became fundamental to the approach taken for the Dialogues project, given one of the aims was to establish a new approach to developing sustainable curriculum content. Moreover, the research insight offered by the publication suggested to us that our project partnership would achieve the best result for all parties where the education activity was meaningful and where students and staff could 'collaborate as individually valued and invested members of a shared learning and academic community' (Healey et al. 2014: 21).

We realized early on that working in partnership with students from both undergraduate and postgraduate levels would be an effective way of developing student engagement, enhancing learning and building platforms for continuing discourse. Moreover, we felt it might encourage student progression from undergraduate into postgraduate study. One of the fundamental aspects of the project was to establish a model of delivery that could be developed year on year as a rolling set of discourses. A primary objective was to develop open opportunities for student engagement, and to encourage student participation in the design of learning activities.

At the beginning of the 2010 academic year, a focus group comprising second-year undergraduate and part-time M.A. Fine Art students was convened. The primary purpose of the meeting was to discuss potential methods for extending learning opportunities, based on the familiar model of lecture and tutorial. We were interested to understand whether students thought that an alternative and more participatory approach might be a valuable addition to their learning experience. The initial feedback suggested that while the lecture format was a very valuable part of their studies, they felt the approach was sometimes didactic, with few opportunities to ask detailed questions about methods and processes resulting from the presentation. Another observation made by both students and staff in the focus group was a tendency for the same minority group of students to ask the majority of questions in the lecture theatre. The feedback suggested that a majority of students found the environment not conducive to speculative enquiry, finding both the environment and size of audience intimidating. The subsequent tutorials (offered by visitors) would put focus back on the student's own enquiry, reducing opportunities for further analysis of the visitors' presentation. The focus group also provided a strong indication that working in partnership to develop new learning experiences would be well received. 
Our intention to integrate teaching and research echoed other considerations for this approach in the sector, and for this project we were keen to extend this approach across both undergraduate and postgraduate students. According to Healey and Jenkins, research events most commonly associated with postgraduate study provide platforms for dialogue and peer review, but these were uncommon within undergraduate teaching strategies despite their potential opportunities for bridging teaching and research practice (Healey and Jenkins 2005). In 2009, the UK HEA had published a report called 'Developing undergraduate research and inquiry', which proposed that 'undergraduate students in all higher education institutions should experience learning through, and about, research and inquiry' (Healey and Jenkins 2009: 3). A few years later in 2012, the Arts University Bournemouth held an HEA workshop - Designs on Learning: The Role of the Undergraduate Research Symposium (2012). Furthermore in 2012, The Guardian held a live web chat called 'Engaging undergraduates in research' and this considered the notion of a research-active curriculum. It suggested that the drive for more researchdriven activity was in part responding to the marketplace and the role of innovative approaches to teaching and learning in attracting new students (Anon. 2012).

This momentum in the sector surfaced in another project at Bournemouth University in which undergraduate research was celebrated in the form of an academic conference. Showcasing Undergraduate Research Excellence (SURE) 2014 was an initiative aimed 'to promote and value undergraduate research [...] across all Schools and levels of study [...] outside the confines of formal assessment' (2015). For the project team, this raised the importance of formative experiential learning. It was important that the Dialogues project would bridge both undergraduate and postgraduate communities and contribute to student learning in the context of a holistic approach to student assessment.

\section{METHODS}

In order to facilitate student engagement, it was decided that the best way to facilitate this was to co-opt students as partners as a central theme in the development of the initial project, and to share responsibility for the rationale, content and organization as a team (HEA 2015). In order to develop a meaningful relationship between students and staff, we adopted the values expressed in the 'UK Quality Code for Higher Education' (2015) to include those of openness, shared goals and values, and regular communication between the partners (QAA 2015).

It was agreed that an open call for team members would be based on proposal, and would be sent out to all Fine Art students approximately two months prior to the event. Proposals that demonstrated a clear benefit to individual learning were selected by academic staff to form the first Dialogues team. From the outset it was agreed that the team should comprise at least one academic member of staff and a group of selected students, and the project would adopt the conference model format. John Adair in 'Effective teambuilding: How to make a winning team' identifies three distinct needs present within a given group, namely the needs or demands of the project or task; the needs or demands of the team; and the needs and demands of the individual members of the team (Adair 1987, cited in Levin 2005). Taking 
Adair's analysis into account, the early consensus informed the team that the project would involve many voices and levels of experience.

Fundamental to this approach was the need to provide what Boud describes as 'a learning environment in which students can explore theories and skills for team management and develop through discovery, their own creative and innovative strategies for achieving team effectiveness' (Boud et al. 2001: 87). It was recognized that to manage the project successfully would involve a careful balance of listening, instruction, overview and project management. It was essential that the influence and choice exercised by students should increase as the project progressed towards an outcome. This echoes Bovill and Bulley's model for a ladder of student participation in curriculum design (see Figure 2), which clearly demonstrates progression through the introduction of choice, from little or no interaction to one where students gain more control over their learning (2011).

The student team considered the roles of the team members and discussed different models for team roles including Belbin's model for

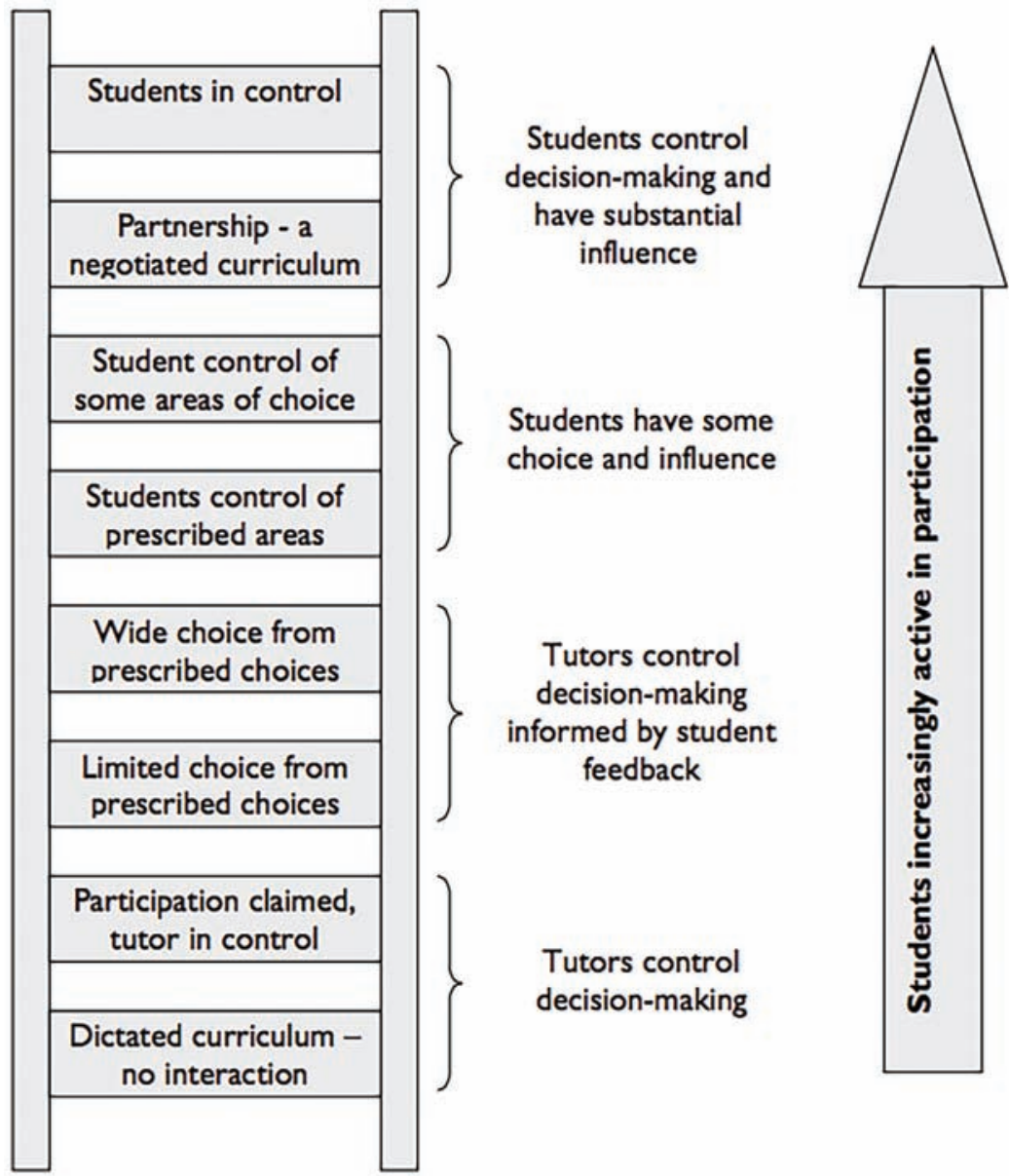

Figure 2: Ladder of student participation in curriculum design (Source: Bovill and Bulley 2011: 176-88). 
archetypal roles such as coordinator, investigator, teamworker and specialist (1996). In a holistic sense, this became a form of skills audit and allowed students of different capabilities and levels of experience to consider the positive contribution they could make in order to further the team's aims for the project.

Once the team had been established, a series of planning discussions informed a collective decision to structure an event split equally between formal presentations (structure and information) based on an overarching theme, and a series of informal 'dialogue' sessions with the visiting speakers (participation). It was felt that this two-part approach would encourage reflective thinking, and allow students to formulate thoughtful and considered questions based on the presentation material. As a result, there were no Q\&A sessions offered immediately following the morning sessions, with students encouraged to save any questions for the afternoon sessions. According to Grace and Gravestock in Inclusion and Diversity: Meeting the Needs of Students, it is 'important that we do not simply teach in a way that we learn best, but in a variety of approaches' (2009: 81). It was therefore decided that a combination of asynchronous learning environments would best suit this approach, utilizing both the Lecture Theatre, seminar rooms, and exhibition spaces according to event. We were aware that students were more likely to engage in dialogue on a face-to-face basis if we interchanged venues from the public space of the auditorium to the more intimate setting of small seminar rooms and exhibition spaces. By programming parallel break-out groups and moving the speakers rather than the audience, a fluid interchange was developed between givers and receivers. This echoes the assertion by Brockbank and McGill in Facilitating reflective learning in higher education that space for dialogue requires a

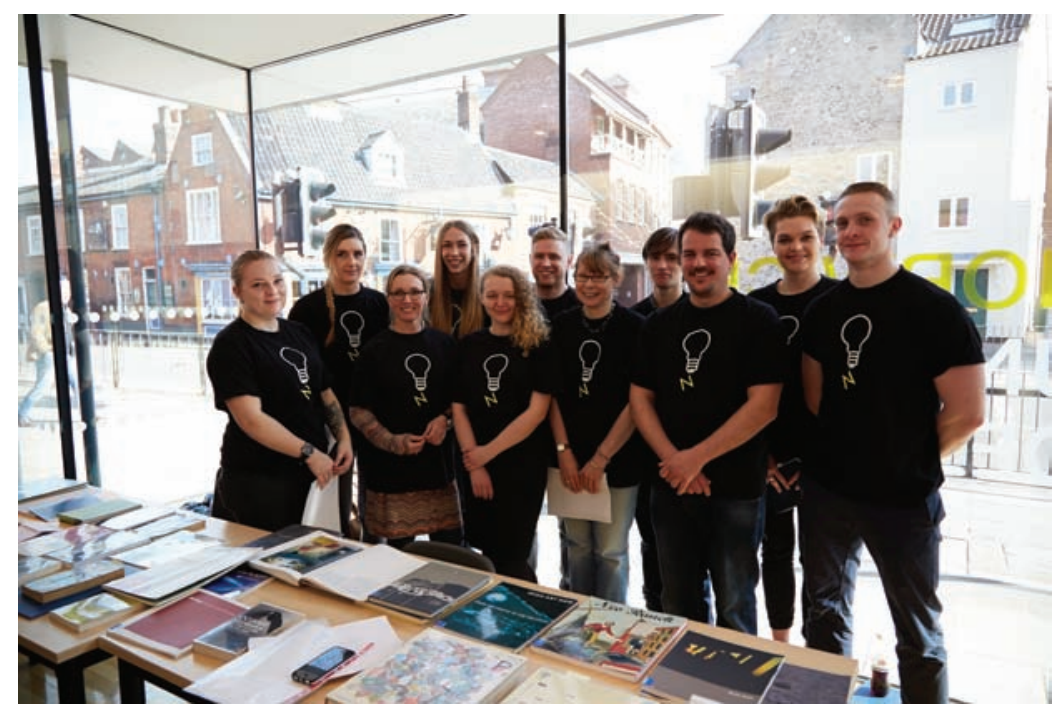

Figure 3: The Dialogues 2014 team included a mixture of B.A. and M.A. students. The team provided a resource area during the symposium and an extensive reading list of associated material (Source: Norwich University of the Arts). 
range of different environments to facilitate maneuverability and flexibility (2000).

At the beginning of each annual project, the team (see Figure 3) would be asked to nominate a student project lead and to devise roles and responsibilities according to the needs identified by the group. The team decided that a conference format would be the most versatile for engaging a broad range of interests across a large student audience. The group established that each project should provide an event, which featured the following:

- A relevant and accessible annual theme

- A blend of early, mid-career and established researchers

- A mixture of formal presentations and informal 'dialogues'

- Opportunities for greater integration and collaboration between B.A. and M.A. students

- Opportunities for student led plenary sessions/related workshops/events

- An emphasis on practice-based research

- A student-led open-call exhibition (B.A./M.A./PGR) based on the theme

- Student-led production of symposium resources (bibliographies, associated literature and related information) to be disseminated post event to all student delegates via e-mail.

\section{THE DIALOGUES PROJECTS 2010-2014: A SYNOPTIC VIEW}

The undergraduate and postgraduate students involved in each of the Dialogues projects have been actively involved in building a successive range of annual events from which a range of spin-off activities have added value to student learning. Through partnership, the Dialogues team have developed asynchronous curriculum content through active research, open forum exchange and discussion with their co-opted partners. Each project has taken on a particular emphasis based on the shared values and goals of both the team and of the academic staff supporting these initiatives. Each theme was chosen to reflect wider professional contexts and themes emerging from the cultural sector. The following synoptic accounts provide a content overview of the Dialogues projects between 2010 and 2014:

Dialogues 2010: Practice Encounters: Platforms for Dialogue was designed to promote and enhance contemporary discourse within the student learning experience, and gained initial seed funding through the University's Teaching and Learning Fund. It comprised two distinct dialogues: a lecture and interactive workshop programme and a two-day symposium. In Dialogue 1, Dr Catherine Baker (Norwich University of the Arts [NUA]) invited the internationally acclaimed artist Hamish Fulton to undertake direct engagement with the student body through their involvement in a series of planned walks. Central to the programming of the Fulton event was the notion of 'direct dialogue' with the artist, through a physical engagement with his methodology for practice. A total of 80 students were selected from the proposal submissions, to form four separate walking groups with Fulton. Roger Ackling (NUA Fine Art Fellow) was one of the other participants. The participants were given instructions for repetitive walking actions, which lasted between two and three hours, facilitated by the members of the Dialogues team. A de-brief with Fulton gave students an insight into a working practice through live encounter. In Dialogue 2, the symposium 
format allowed a shift away from the notion of a singular examination of an artistic practice, to a more pluralistic, bringing together of different ideas, approaches and concerns that would allow students to engage in meaningful and constructive discussion and dialogue. In order to foster inclusivity the team decided that our first symposium in 2010 should investigate the currency of drawing, as an activity pivotal to so many of the mechanisms of fine art practice. Speakers included Emma Stibbon (Artist), Claude Heath (Artist), Stephen Felmingham (Artist) and Katayoun Dowlatshahi (Artist), who discussed a range of approaches and methodologies concerned with contemporary drawing practice.

Dialogues 2011: Between the Real and the Imaginary was centred on the notion of a threshold or encounter with the world, explored through real or fictitious narratives. Geraint Evans discussed how his practice engages with our perception or encounter with landscape, uncovering an uneasy dialogue between the natural and the real. Kathleen Fox (Artist) and Professor Krzysztof Fijalkowski (Curator) discussed their collaborative project, 'The Spaces of the Unconscious', exhibited at the Freud Museum, London (2010). The exhibition, which took the form of a multimedia installation, explored the threshold between the conscious and the unconscious, negotiating a space between the real and the imaginary. Harriet Godwin (Curator) gave an insight into her work on the Visual Dialogues project (a Tate partnership project at Norwich Castle Museum and Art Gallery), whose primary aim was to generate creative responses to their collections through visual dialogue between historic and contemporary works of art.

The third iteration, Dialogues 2012: States of Being: Material, Incident, Transformation, considered a range of diverse approaches to artistic practice, which probe and explore the meaning generated by materials. The symposium examined the rise to prominence of artists such as Claire Barclay and Turner prize nominee Karla Black within recent British sculptural practice, and the resurgence of interest in the use of materials to evoke a sense of transformation, ambiguity and encounter. Dialogues 2012 explored different approaches to this encounter including a consideration by Professor Neil Powell (Artist/Academic) of Mono-ha, a group of artists working in Japan in the late 1960s: the subtle transformation and disruption of meaning in the work of Sara MacKillop (Artist); and the fractured, architectonic collaged works of Mark Harris (Artist). Commonalities occurred throughout the work in discussion, in acts of spontaneity, of unaltered states, of the bringing together or rearrangement of disparate forms to create new and complex narratives.

Dialogues 2013: On Shifting Ground: The Endurance of Abstract Painting responded to and reflected upon the dialogue and re-examination of the status of abstract painting, which had been generated by a number of contemporary exhibitions, survey shows and publications. It was discussed that many of these have continued to successfully engage the public with notions of abstraction, and with abstract painting in particular. The title On Shifting Ground: The Endurance of Abstract Painting acknowledged both the history and legacy of abstract painting, its continued relevance for contemporary artists working today, and reflected upon the continually moving terrain in which it operates. The papers and dialogues discussed the history of abstraction within painting with many likening this to a long and involving story, one accompanied by notions of radicalism, revolution, 
detachment and a sense of impending collapse. In a contemporary culture where artists now compete with an endless array of information, visual languages and histories, it was argued that painting continues to defy the gravitational pull of its much anticipated demise, and remains an urgent and exacting exponent of visual arts practice. Speakers included Sarah Shalgosky (Curator), Narbi Price (Artist), Michael Brick (Artist) and Simon Granger (Artist).

Dialogues 2014: Place, Space and Negotiated Territories provided an opportunity to reflect upon the continuing interest in the questions of space and place. In 'Of other spaces: Utopias and heterotopias', Foucault identifies space as 'the great anxiety of our time' (1984). This was reflected during the symposium, which highlighted the increasing number of artists who continue to question our relationship to the environments that we inhabit, both physically and in our imaginations. In particular, it set out to understand how we negotiate our way through the physical world that we live in, and questioned when does a space become a place? Speakers included Dr Maryclare Foa, Dr Polly Gould, Dr Dan Hays and Dr Judith Stewart (co-convener). Of particular note, Dr Polly Gould enlisted volunteers from the Dialogues team to read aloud extracts during her lecture, and in doing so further embedded student participation within the framework of the symposium. The presentations and dialogues sessions examined a range of associated themes, outcomes and methodologies including conditions pertaining to the urban environment, psycho-geographies, and landscape, identity and cultural memory.

\section{PROJECT IMPACT}

This student-focused project had been originally conceived to provide an experience that would combine relevant learning material within the framework of a supportive learning environment. The format was designed to encourage dialogue (and occasionally collaboration) across the student body in a research-engaged environment in which all students would gain professional understanding and subject knowledge through active participation. Many parts of the project were given over to students to self-direct, with focus groups providing space for evaluation of student perceptions of the project as it developed (Prosser and Trigwell 2001). The project aims had been established to further integrate research and teaching and to enhance student engagement, dialogue and the promotion of critical reflection. By employing a combination of verbal dialogue in-situ, and written reflection post-event (through reflective journals maintained at both undergraduate and postgraduate levels), the project echoes Kolb's assertion that the use of reflection promotes the translation of experience into learning and simultaneously encourages students to adopt a more strategic approach to individual research (1984). Following each project, evidence of this critical reflection could clearly be seen in supporting documentation provided for assessment at both undergraduate and postgraduate levels.

Dissemination of the project through staff for uses such as university learning and teaching days and research events has allowed the project team to reflect on the impact of what Trigwell and Shale term 'pedagogic resonance' (2004) with other academic departments. Writing in 'Student learning and the scholarship of university teaching', they describe this resonance as a bridge between teaching and learning, identifying that 'it is the effect 


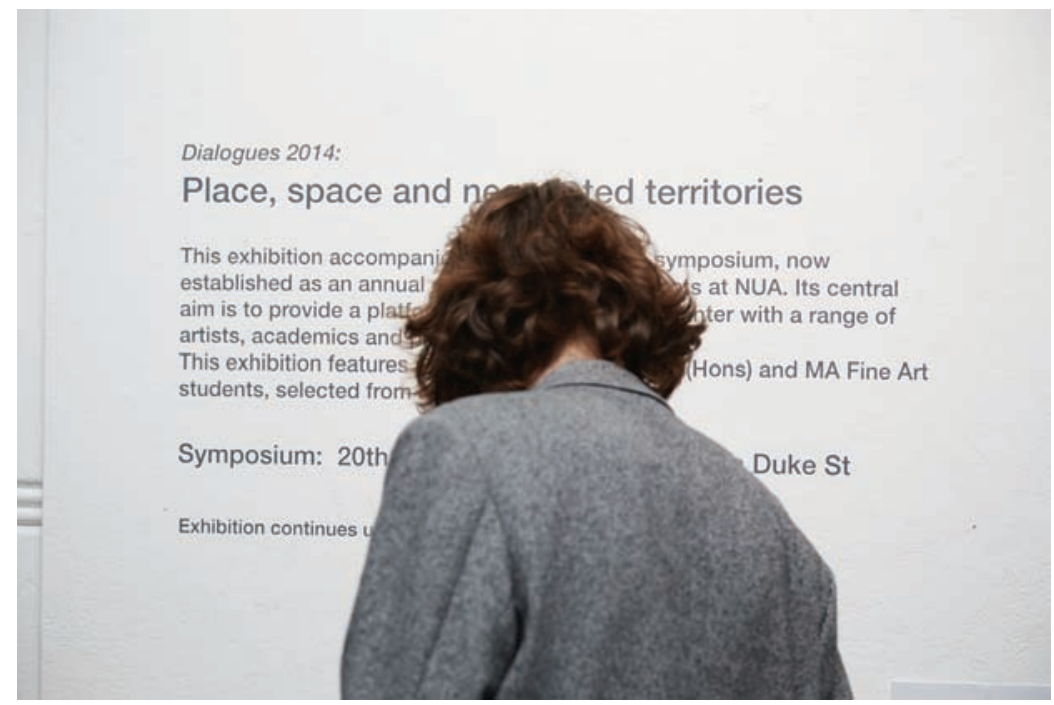

Figure 4: Dialogues 2014 exhibition: visitor reading wall text (Source: Norwich University of the Arts).

of pedagogic resonance that is experienced by students' (Trigwell and Shale 2004: 29, 523-36). Understanding and learning from this experience has been a fundamental part of developing a sustainable approach to the project's legacy. Following each iteration, action resulting from reflective practice enabled change to accommodate the pressures of increased participation, and, as a result, the growing diversity of participants. The ability to adapt the format without compromising the aims of the original project, have been an important part in the development of the annual programme, ensuring it has remained relevant and purposeful. In 2013, the Dialogues team introduced an exhibition component to the project helping reinforce the underlying thematic of practice-led research (see Figure 4). This addressed the drop off in numbers for the final plenary stages of the previous year's symposium, helping to sustain high student engagement throughout the day. In 2014 and 2015, participant numbers had risen to approximately 270 students for each event.

In 2014, two M.A. students used the Dialogues project as the subject of their own pedagogic enquiry, producing an academic poster (see Figure 5) to support their collaborative research into interdisciplinary approaches to teaching and learning. This cited the project as a sustainable model for the integration of undergraduate and postgraduate students. The project itself is now embedded in course literature as part of the formal curriculum for both undergraduate and postgraduate fine art students at Norwich University of the Arts. It has itself engendered satellite initiatives that embrace the methodology of integrated delivery and partnerships, with specific focus on associated aspects of professional practice and employability. The legacy of the Dialogues project has provided a structural and sustainable template for the building of bridges between academic communities, and encouraged dialogue through researchengaged learning. 


\section{DIALOGUES 2014 Norwich University of the Arts}

Sarah Foyster, MA Fine Art Student, NUA

Juan-Jose Guerra-Valiente, MA Fine Art Student, NUA

Paul Fieldsend-Danks. MA Leoder. NUA. Senior Fellow of the Higher Education Acodemy

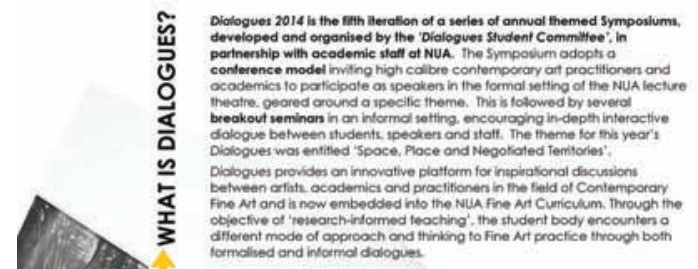

Throughout the Sympoivm, a dedicated academic resource orea wor set up and run by students for review, Resoucces presented were chosen for theis direct relevance to the theme and included films, books, articles, fexts ond of

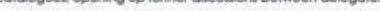
in oddition, a Dialogues 2014 Exhibilion was devioned and organised by students from an Open Cal, open fo al year groups ocrosts both Undergraduate

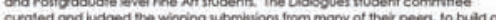
curated and judped the winning lubmisions from many of their peen, Ho buad a were desioned to coincide with the end of the Sympotium and all Univenity

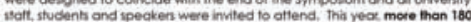
atudent delegater alongside acodervic utatt, attended Diologues 2014 and the Dialogues Echibition

Dialogues is now firmly establihed within NUA as an arnual feature of the fine Af academic colendar and the benefits ore mutualy opporent to both sides of the

Partinestip

- A Mighly eflective partnership enterprive has been detioned as a unique colloborasion and engogement between students and acodemic statt.

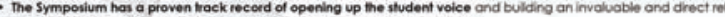

thoughoul the rne

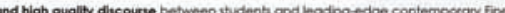

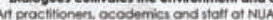

- Students and statt lead and engoge in a series of peofersiond cross-diccipinary lectures and interactive seminan with speaken to ensute that the studert

delegales are aven the ifontidence to divcuss, citique and chalenge the themes and concepts raved.

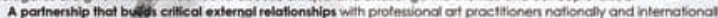
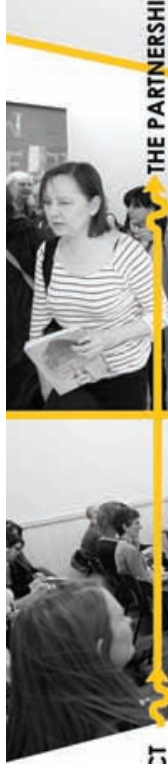

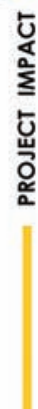

There has been much positive leedbock from itudents and their octive leaning experience through the Dialoguer Symporium:
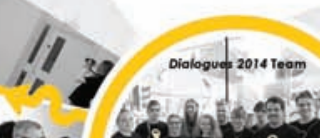

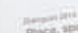

$$
\text { , }
$$
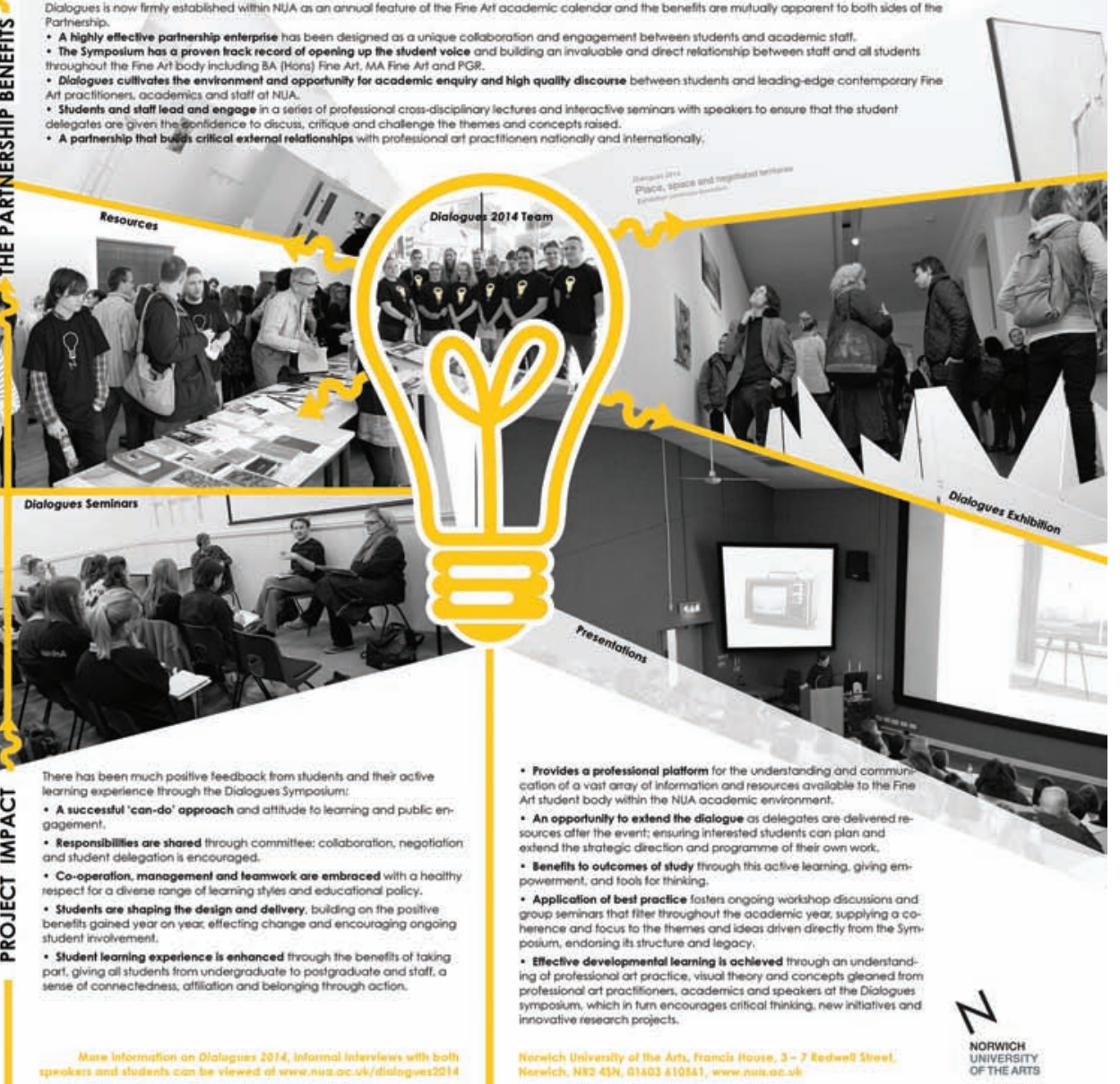

- A succes

- Responsibillites are shared through con

- Co.operation, manogement and leamwork are embroced with a heoithy

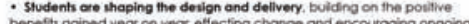
benefits gained year on yeca. effecting change and encouraging ongoing

- Student looming oxpo

pat

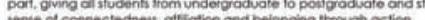

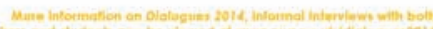

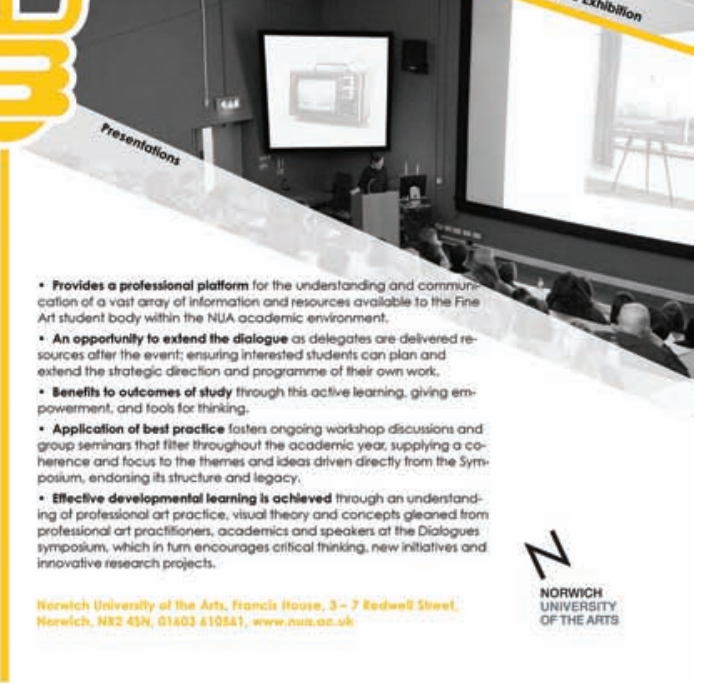

Figure 5: Dialogues 2014 academic poster produced by M.A. students (Source: Norwich University of the Arts). 


\section{REFERENCES}

Adair, J. (1987), 'Effective teambuilding: How to make a winning team', cited in P. Levin (2005), Successful Teamwork: For Undergraduate and Taught Postgraduates Working on Group Projects, Maidenhead: Open University Press.

Anon. (2012), 'Engaging undergraduates in research', The Guardian, 13 January, http://www.theguardian.com/higher-education-network/blog/2012/ jan/11/undergraduate-research. Accessed 2 May 2015.

Belbin, R. (1996), Management Teams: Why they Succeed or Fail, Oxford: Butterworth-Heinemann.

Boud, D., Cohen, R. and Sampson, J. (2001), Peer Learning in Higher Education, London: Kogan.

Bovill, C. and Bulley, C. J. (2011), 'A model of active student participation in curriculum design: Exploring desirability and possibility', in C. Rust (ed.), Improving Student Learning (18) Global Theories and Local Practices: Institutional, Disciplinary and Cultural Variations, Oxford: The Oxford Centre for Staff and Educational Development, pp. 176-88.

Brockbank, A. and McGill, I. (2000), Facilitating Reflective Learning in Higher Education, Buckingham: SRHE and Open University Press.

Department for Business, Innovation and Skills (BIS) (2011), 'Students at the heart of the system', Higher Education White Paper, https://www.gov. uk/government/uploads/system/uploads/attachment_data/file/31384/11944-higher-education-students-at-heart-of-system.pdf. Accessed 25 May 2015.

Foucault, M. (1984), 'Of other spaces: Utopias and heterotopias', http:// foucault.info//documents/heterotopia/foucault.heterotopia.en.html. Accessed 25 April 2015.

Grace, S. and Gravestock, P. (2009), Inclusion and Diversity: Meeting the needs of all Students, Abingdon: Routledge.

Healey, M. and Jenkins, A. (2005), Institutional Strategies to Link Teaching and Research, York: Higher Education Academy.

- (2009), 'Developing undergraduate research and inquiry', York: Higher Education Academy, www.heacademy.ac.uk/assets/York/documents/ resources/publications/DevelopingUndergraduate_Final.pdf. Accessed 2 April 2015.

Healey, M., Flint, A. and Harrington, K. (2014), Engagement through Partnerships; Students as Partners in Learning and Teaching in Higher Education, York: Higher Education Academy.

Higher Education Academy (HEA) (2012), Designs on Research: The Role of the Undergraduate Research Symposium, Arts University College at Bournemouth, Poole, UK, 25 June, http://networksadm.blogspot.co.uk/ 2012/04/event-designs-on-research-role-of.html. Accessed 16 April 2015. - (2014), Framework for Partnership in Learning and Teaching in Higher Education, York: Higher Education Academy.

_ (2015), 'Students as partners', https://www.heacademy.ac.uk/enhancement/themes/students-partners. Accessed 15 April 2015.

Kolb, D. A. (1984), Experiential Learning, Englewood Cliffs, NJ: Prentice-Hall.

Prosser, M. and Trigwell, K. (2001), Understanding Learning and Teaching: The Experience in Higher Education, Buckingham: SRHE/Open University Press.

Quality Assurance Agency for Higher Education (QAA) (2015), UK Quality Code for Higher Education, Part B: Assuring and Enhancing Academic Quality Chapter B5: Student Engagement, Gloucester: QAA. 
Ramsden, P. (2006), Learning to Teach in Higher Education, London: Routledge.

Showcasing Undergraduate Research Excellence (SURE) (2015), SURE Conference, Bournemouth University, Poole, UK, 2 March, http://surebu. org.uk/calendar/sure-conference/. Accessed 10 March 2015.

Trigwell, K. and Shale, S. (2004), 'Student learning and the scholarship of university teaching', Studies in Higher Education, 29: 4, pp. 523-536.

University of Lincoln (2013), 'Student as producer', http://studentasproducer. lincoln.ac.uk/. Accessed 25 April 2015.

\section{SUGGESTED CITATION}

Fieldsend-Danks, P. (2016), 'The Dialogues project: Students as partners in developing research-engaged learning', Art, Design \& Communication in Higher Education, 15: 1, pp. 89-102, doi: 10.1386/adch.15.1.89_1

\section{CONTRIBUTOR DETAILS}

Paul Fieldsend-Danks is the Head of Taught Postgraduate Awards at Norwich University of the Arts. Paul holds a B.A. Fine Art from Newcastle University, and an M.A. European Fine Art from Winchester School of Art (University of Southampton). His research interests include the expanded field of contemporary drawing practice in a Fine Art context, and various aspects of art and design pedagogy in higher education, including approaches to interdisciplinary teaching and learning. Paul's practice is largely concerned with the materiality of drawing, and his work has been exhibited in a wide range of drawing-related projects. He was shortlisted for the Jerwood Drawing Prize in 2010, and has exhibited in the United Kingdom, Germany, Denmark, Spain, Switzerland, the United States, Japan and Australia. Paul is currently on the editorial board for Drawing: Research, Theory, Practice published by Intellect, and a co-editor of the drawing research journal Tracey, published by Loughborough University, for which he was a co-director between 20112014. He is a Senior Fellow of the Higher Education Academy.

Contact: Norwich University of the Arts, Francis House, 3-7 Redwell Street, Norwich, Norfolk, NR2 4SN, UK.

E-mail: p.fieldsend-danks@nua.ac.uk

Paul Fieldsend-Danks has asserted his under the Copyright, Designs and Patents Act, 1988, to be identified as the author of this work in the format that was submitted to Intellect Ltd. 